\title{
Dødelighet av hjerteinfarkt
}

I løpet av de siste 70 år har det vært dramatiske endringer i dødeligheten av hjerte- og karsykdommer i Norge. I første halvdel av det forrige århundre økte dødeligheten jevnt, men falt markert under den annen verdenskrig. I en klassisk studie fra 1950 beskrev Strøm \& Jensen nedgangen i dødelighet av kardiovaskulære sykdommer under krigen. Studien peker mot miljøfaktorenes sentrale betydning for utvikling av hjerte- og karsykdommer (1). Endringene i kostholdet under krigen innebar mindre inntak av energi og mindre fett. I tillegg røykte man mindre og var mer fysisk aktiv. Strøm \& Jensen viste dermed at dødelighet av hjerte- og karsykdommer kan endres raskt i takt med endringer i levesett.

I årene etter krigen økte dødeligheten av iskemisk hjertesykdom sterkt, særlig blant yngre og middelaldrende menn. Dette førte til $ø \mathrm{kt}$ totaldødelighet slik at forventet levealder for menn gikk ned i perioden 1955-75, for første gang i nyere tid (2). I dette nummer av Tidsskriftet beskriver Reikvam \& Hagen dødeligheten av hjerteinfarkt for perioden 1969-2007 (3). Forfatterne finner at dødeligheten har falt sterkt fra slutten av 1980-årene og frem til 2007. Reduksjonen startet først for de yngste aldersgruppene, og var sterkere blant menn enn blant kvinner. Andelen som dør av hjerteog karsykdom her i landet har dermed sunket fra 50\% i 1975 til $33 \%$ i 2009, og dødeligheten av hjerteinfarkt er nå nede på samme nivå som i tiden umiddelbart etter krigen (2).

Internasjonale data viser at størstedelen (50-75\%) av reduksjonen i dødelighet av hjerteinfarkt skyldes reduserte nivåer i befolkningen av de klassiske risikofaktorene høyt kolesterolnivå, røyking og høyt blodtrykk (4). I Sverige sank kolesterolnivået med 10,4\% fra 1986 til 2002. Denne reduksjonen forklarte alene $39 \%$ av nedgangen i hjertedødeligheten (5). Selv om fysisk inaktivitet, overvekt og diabetes mellitus samlet påvirker dødeligheten i ugunstig retning, er effekten langt fra sterk nok til å motvirke betydningen av kolesterolnivå og røyking.

Medisinsk behandling forklarer i de fleste studier den resterende andelen $(25-50 \%)$ av reduksjonen i dødelighet av hjerteinfarkt. Medikamentene betyr mest, særlig acetylsalisylsyre, betablokkere, ACE-hemmere, og statiner $(4,5)$. Revaskulariserende behandling med perkutan koronar angioplastikk og kirurgi har bidratt noe, men de fleste studiene er utført før slik behandling ble utbredt.

Samlet sett er det solid dokumentasjon for at nedgangen i dødelighet av hjerteinfarkt skyldes endringer i risikofaktorer og behandling, som i sin tur påvirker insidens av sykdommen og prognose for dem som rammes. I studien WHO MONICA fant man at to tredeler av reduksjonen i dødelighet var relatert til redusert insidens av hjerteinfarkt, mens en tredel kunne forklares ved redusert letalitet (6). I USA falt insidensen av akutt hjerteinfarkt med $25 \%$ i perioden 2000-09, hovedsakelig drevet av redusert insidens av hjerteinfarkt med ST-segmentelevasjon i EKG, mens letalitet de første 30 dager sank fra 10,5\% til 7,8 \% (7). Helseundersøkelsen i Troms $\varnothing$ viser en betydelig reduksjon av første gangs hjerteinfarkt hos yngre og middelaldrende menn for perioden 1974-2004, mens det hos kvinner noe overraskende var en økning (8). Prognosen etter hjerteinfarkt ble bedre hos både menn og kvinner.

Norske forskere har bidratt til å dokumentere betydningen av de klassiske risikofaktorene for hjerteinfarkt. En artikkel av Holme \&
Tonstad i dette nummer av Tidsskriftet viser at totalkolesterolnivå, blodtrykk og røyking også predikerer totalmortalitet blant menn i Oslo-undersøkelsen (9). Sannsynligvis har endringer i kolesterolnivå og røykevaner bidratt vesentlig til forløpet av den norske hjerteinfarktepidemien. Fra 1970-årene er kolesterolnivået redusert med ca. $10 \%$, og andelen røykere er halvert (10).

Men kampen mot hjerteinfarktepidemien er langt fra vunnet, verken her til lands eller internasjonalt. Globalt står vi tvert imot overfor en massiv økning av kardiovaskulær sykdom på grunn av ugunstige risikofaktorer i land med lavt og middels høyt inntektsnivå (11). I enkelte rike land er nedgangen stoppet opp, og i USA har man blant kvinner sett økt dødelighet av hjerteinfarkt de senere år (12). Også i Norge har nedgangen i infarktdødelighet flatet ut (3), fremdeles har sju av ti nordmenn for høyt kolesterolnivå, og vi har betydelige sosioøkonomiske gradienter når det gjelder risikofaktornivå og dødelighet (10). Og hva med kvinnene? I Norge var det i 2008 flere kvinner enn menn i aldersgruppen 16-74 år som røykte (10). Røyking har ført til økt forekomst av lungekreft og kols blant kvinner og kan bidra til at insidenstrender for hjerteinfarkt ikke er like gunstige for kvinner som for menn $(8,12)$. Høyere levealder vil føre til økt antall hjerteinfarkter i den eldre del av befolkningen og økende antall pasienter med kronisk hjertesykdom. Vi må derfor fortsatt sette søkelyset både på forebygging og på behandling av hjerteinfarkt.

\section{Kaare Harald Bønaa}

kaare.harald.bonaa@ntnu.no

Kaare Harald Bønaa er professor i hjerte- og karsykdommenes epidemiologi ved Norges teknisk-naturvitenskapelige universitet, og overlege i intervensjonskardiologi ved Hjertemedisinsk avdeling, St. Olavs hospital.

\section{Oppgitte interessekonflikter: Ingen}

\section{Litteratur}

. Strøm A, Jensen RA. Mortality from circulatory diseases in Norway 1940-1945 Lancet 1950; 1: 126-9.

2. Statistisk sentralbyrå. www.ssb.no/emner (15.2.2011).

3. Reikvam Å, Hagen TP. Endringer i dødelighet av hjerteinfarkt. Tidsskr Nor Legeforen 2011: 131: 468-70.

4. Ford ES, Ajani UA, Croft JB et al. Explaining the decrease in US deaths from coronary disease, 1980-2000. N Engl J Med 2007; 356: 2388-98.

5. Björck L, Rosengren A, Bennett $\mathrm{K}$ et al. Modelling the decreasing coronary heart disease mortality in Sweden between 1986 and 2002. Eur Heart J 2009; 30: $1046-56$.

6. Tunstall-Pedoe H, Kuulasmaa K, Mähönen M et al. Contribution of trends in survival and coronary-event rates to changes in coronary heart disease mortality: 10 -year results from 37 WHO MONICA project populations. Monitoring trends and determinants in cardiovascular disease Lancet 1999. 353: 1547-57.

7. Yeh RW, Sidney S, Chandra M et al. Population trends in the incidence and outcomes of acute myocardial infarction. N Engl J Med 2010; 362: 2155-65.

8. Mannsverk J. Insidens og case fatality av førstegangs hjerteinfarkt i Troms $\varnothing$ kommune 1974-2004. Abstrakt. Hjerteforum 2009; 22: 88-9.

9. Holme I, Tonstad S. Risikofaktorer og dødelighet - oppfølging av Oslo-undersøkelsen fra 1972-73. Tidsskr Nor Legeforen 2011; 131: 456-60.

10. Folkehelseinstituttet. www.norgeshelsa.no (15.2.2011)

11. Anand SS, Yusuf S. Stemming the global tsunami of cardiovascular disease. Lancet 2011: 377: 529-32.

12. Ford ES, Capewell S. Coronary heart disease mortality among young adults in th U.S. from 1980 through 2002. Concealed leveling of mortality rates. J Am Coll Cardiol 2007; 50: 2128-32. 